\title{
Personality Assessment Aspectsand Radicalizationin Prisons ${ }^{1}$
}

\author{
David Krámský \\ Charles University \\ Faculty of Education \\ Police Academy \\ BarboraVegrichtová \\ Czech Technical University \\ Faculty of Biomedical Engineering
}

\begin{abstract}
Theprison facilityis generally considered as an environment with a corrective purpose. Besides the social sense of remedy, prison is also an environment that potentially determines and affects socially dangerous behavior. The authors, based on long-term empirical research, present the significant indicators that are directly related to the transformation of personality attitudes, motivations and behavior associating with a process of radicalization. One of the most significant symptoms of radicalization is a particular social and moral decision making. Individuals in the radicalism process primarily prefer utilitarian manners in their decision-making rather than personal aspects like empathy for others. The authors will present the method of social-moral profiling of a subject in radicalization process as an effective prevention system which reduces security risks in society.
\end{abstract}

Key words: radicalism, indicators, social profile, moral decision

\section{Introduction}

Radicalisation posesa security phenomenon which is frequently discussed in the security community and academic sphere as well. The problem of radicalisation has been increased in the recent years, mainly in connection with terrorist recruitment and following violent attacks. Many experts try to reveal crucial push and pull factors of radicalisation process. Recruiters use many tactics and narratives in order to spread radical ideas and influence new devoted members. The specialists from different academic institutions have been studied different terrorist groups across the world. The crucial point of preventing terrorism is a prompt and on time detection of radicalisation process in early stage in order to launch appropriate intervention. Recent findings of research projects show the important fact, some environments are more vulnerable to radicalisation and terrorist recruitment than the others. One of these places represents the correctional facilities and prisons. It is utmost important for effective prevention to raise awareness about this issue and underlying multi agency approach in this field. Well educated staff of prison facilities and the cooperation of different relevant institutions including probation and mediation services, nongovernmental organisation, psychologists, special pedagogues and academic employees is a key element in the continuous effort to reduce radicalisation and terrorist recruitment in prison facilities.

\section{Radicalization in Prisons}

Prison facilities are generally perceived as a risky environment due to the apparent cumulation of persons with criminal backgrounds, inclinations to recidivism and socially pathological behavior. At the same time, it is a place with a higher psychological vulnerability of prisoners in terms of predispositions and tendencies towards defective behavior or the potential risk of radicalization. Radicalization and, at the same time, deradicalization is (at present) a central theme of debates of a security and political nature in a pan-European context. The basis is the opportunity and at the same time the ability of contemporary society and its competent institutions to identify (in time) the progressing radicalization process of particular individuals in selected social segments. Early detection of warning signals indicating the progressive course of radicalization thatwill allow the initiation of deradicalization measures and other effective measures of prophylactic and safety character.

\footnotetext{
${ }^{1}$ Supported by Ministry of the Interior of the Czech Republic, project No. VI20192022117, Detection of Radicalization in the context of population and soft targets protection from violent incidents.
} 
Successfully capturing the risk symptoms appearing in persons serving imprisonment is possible only if knowledge of the mechanisms and dynamics of radicalization processes is known. Professional intervention and the proactive response of security staff and other relevant security services is crucial for the elimination of these symptoms or (possibly) for averting threats related to violent extremism and terrorist attacks. The most cited and almost flagrant example of radicalization in prisons is the case associated with Richard Reid (born in 1973) known as the Shoe Bomber. This is a British citizen who attempted, on 22 December 2001, to initiate an explosive which he had hidden in footwear on an American Airlines flight (Flight No. 63, from Paris to Miami). Reid converted to Islam during his stay in British Prisons.

After his release, he left to Pakistan and Afghanistan, where he trained and became a member of Al-Qaeda. The attempted terrorist attack was unsuccessful. Reid was unable to detonate the explosive andhe was detained and arrested after the plane had landed in Boston. In 2002, he was found guilty and sentenced to three life sentences and 110 years imprisonment without the possibility of release. He is currently imprisoned in the highest security prisons in the United States of America (so called super maximum security prisons). His case is often subjected to an analysis of expert workplaces and experts in order to find answers to questions about the roots and causes of his radicalization in prisons. Due to the small amount of information about the time spent in the correctional facility and the complications while detecting valid data, the outputs of these studies are rather speculative. Radicalization in prisons continues, however, even today. The perpetrator of the terrorist attack in Berlin in December 2016 also underwent the process of radicalization in prison. The attacker hauled a truck into visitors at a Christmas market. Twelvepeoplewerekilled and manyinjured. The attacker named Anis Amri spent four years in an Italian prison where he was radicalized. This information was published by the Italian Prison Office in a report submitted to the governmental anti-terrorist commission. According to available information, Amri hadundergone a rapid process of radicalization and become a fanatical confessor of Islamic extremism who intimidated other fellow prisoners (believers of the Christian faith). ${ }^{2}$

The criminal environment and the prison community is not naturally the only environment more prone to radicalization processes. The school environment, meeting places for youth, similar platforms like clubs, groups, or even gangs of juvenile delinquents can be a base and, at the same time, recruitment pool for terrorist and extremist organizations. Young people and young adults naturally tend to admit radical ideas, unconventional attitudes, but also extremist ideologies. In most cases, young people are not burdened with existential problems or family concerns. Their value ranks are in progress, they are flexible and their personality is usually still not completely formed (as well as their opinions). The period of adolescence is accompanied by an effort to define yourself within a reference group, to gain a respectable status in the peer hierarchy, andto achieve admiration and respect. The combination of the above mentioned characteristics creates the ideal place for extremists' recruiting efforts. Prison facilities are (however) a much more risky territory, since prisoners (especially recidivists) already have direct experience with illegal activities. They can move in and adapt to non-standard conditions, and (in many ways) have already encountered various forms of violence. Violence itself represents the normal way of achieving goals or removing obstacles to their achievement. It is not necessary to emphasize the fact that the prison population represents a very heterogeneous environment, and the above mentioned concept cannot be generalized to all individuals. It is obvious, however, that prisoners are more predisposed to ideological or religious radicalization than the conformist and mainstream society, given the criminal past and the context of correctional facilities conditions.

Given the above characteristics, it is logical that the prison environment is logically called the breeding ground of radicalization processes. A person who finds himself in such a mental state, a personal crisis or a life defeatism can be an easy target for the recruiting efforts of extremist organizations or, better, their representatives who are also in prison. This is the second aspect that makes the prison environment a very risky platform for radicalization processes.

The prison system accumulates (during theirimprisonment) persons with criminal experience who can be freely categorized into two basic groups. On the one hand, there is a wide range of offenders of variable crime (the so-called traditional type or general criminality). These are (in particular) drug offenders, property or violent criminals, whose actions are usually motivated by profitability, desire for personal enrichment or other profit, or are the result of another psychopathological action or attitude. Some authors ${ }^{3}$ refer to this group as "mainstream prisoners" or the main line of the prison population.

\footnotetext{
${ }^{2}$ FAIOLA, A., KOTTOOR, N. and PITRELLI, S.Suspect in Berlin market attack was radicalized in an Italian jail. [online]. [cit. 2.7.2017]. Available at: https://www.washingtonpost.com/world/europe-searches-for-suspect-berlin-christmas-marketattack/2016/12/22/78502d7e-c7e0-11e6-acda-59924caa2450_story.html?utm_term=.56204354c9cd

${ }^{3}$ See JONES, R. C. (2014). Are prisons really schools for terrorism? Challenging the rhetoric on prison radicalization., Punishment and Society. Australia: Australian National University,16, 1, 74-103.
} 
However, the second category of imprisoned persons is made up of supporters, advocates, or executors of extremist attitudes and actions. Their unlawful conduct is usually motivated ideologically, by some kind of conviction or ideological fanaticism. The presence of these people in prisons and their day-to-day contact with other fellow prisoners can lead to the (so-called) ideological plague and recruitmentofnew sympathizers and followers.Effective steps to identify and limit intentional radicalization in prisons require the understanding of its basic procedural mechanisms and the well-timed identification of its symptoms.

It is an indisputable fact that radicalization in prisons is a serious social and security phenomenon that has not only a local but (in many ways) an international overlap. Thus, the key issue is not whether radicalized persons are present in prisons but how to identify them. As it has been described above, radicalization processes take place at different levels, including interpersonal transformations. Internal processes of personality transformation are difficult to detect for direct observers. Therefore, the detection of external signals (which are objectively observable) is decisive. Such signals are called the indicators of the radicalization process.

Under this designation we understand in the outside world perceived (visual) manifestations and changes of the appearance, behavior, or acting of the person which indicate that the individual is in the process of radicalization. The very symptom of radicalization does not bring the evidence that this individual is capable and willing to commit acts of violent extremism or terrorism. Individual indicators, i.e. changes in behavior and acting, cannot serve as a clear and indisputable proof of involvement in a terrorist organization. These indicators serve only as warning signs, which are basically one of the indications of risky behavior or the development of specific personality. To identify a radicalized person, it is necessary to evaluate the detected symptoms in a comprehensive and interrelated context. There is no universal methodology applicable to many cases of the same kind. As it has been highlighted above, radicalization is an individual and variable process.

An objective assessment of the amount of registered symptoms requires the knowledge of the different radicalization indicators and their categories and their links to extremist forms and ideologies. At the same time, however, it should be noted that some of the symptoms are identical to indicators of personality radicalization. This does not have to be initiated or to have a direct link to ideological doctrines. These are usually acts of so-called solitary wolves, or active shooters (active shooters or attackers), who were (by externalities combined with mental processes or illnesses) led to the realization of a violent act.However, the motivation to carry out a violent act (in the case of the above-mentioned actors) may not be motivated by ideology or religion. In these cases, the feeling of the long-term hopelessness of a frustrated individual in a certain life situation or (at least) a defeatist subjective experience of such a situation can play a key role. The individual experience and the actual state do not always have to be identical and correspond to objective reality. The perception of injustice is always a very subjective matter and many banal situations (that are insignificant to the environment) can represent a key trigger mechanism for the individual concerned. Such situation can accelerate the entire chain of events, which may end up in a tragic and destructive manner.

The majority of recent researches list the following categories as the most common radicalization indicators:

1. Self-identification (the way an individual perceives his or her own personality)

2. Us vs. Them concept of seeing the world (the individual perceives society as opposition)

3. Social interactions (the way an individual behaves in society)

4. Personality level (personality characteristics and the expression of emotions)

5. Associations (links to a radical group, or the manifestations of association with a radical group).

A similar categorization is provided by COPPRA. It distinguishes between two sets of indicators, i.e. indicators whichindicate ongoing radicalization and indicators whichindicate preparation for violent action. Within both categories, there may be identical symptoms that are reflected on three levels of identity,ideology, and behavior. Theseindicators need to be evaluated in the overall context. The manifestation or occurrence of one of the indicators may not yet be a symptom of the radicalization process. Incorrect indicator evaluation can have the opposite effect and work (conversely) as a push factor, the accelerator of the radicalization process.In connection with prison environment, the following attributes can be considered as the possible indicators of radicalization process: ownership of promotional materials, books and DVDs; change of belief or religion and its practice; participation in closed meetings of the prison community; glorification of violence or martyrdom; more frequent verbal violence and offensive rhetoric; watching selected TV genres and listening to violent music; social isolation and conscious separation from routine prison life; changing of attitudes towards other fellow prisoners; more frequent use of radical terminology and slang expressions; change of appearance, dressing, symbolism; specific tattoos; disciplinary offenses and manifestations of disrespect towards prison staff. A comprehensive list of indicators relating to the process of radicalization cannot be presented, and such an effort would not be efficient. Indicators of radicalization are external symptoms, pointers containing information which (in their total number) determine whether or to what extent a person is radicalized. 
It should be emphasized that the identification of radicalization of a particular person is not the goal itself. It is the primary impuls for the launch of the deradicalization process (as well as for the adoption of other preventive measures and security).

\section{Methodological Problems and Personality Aspects}

The identification of the highly radicalized individual today is based largely on the empirical observation of external characters, such as behavioral manifestations (see the previous section). As with other similar observation studies, the manifestations of behavior may not fully correlate with reality. While the investigated subject may behave in the prison environment (and his ways of expression can also flagrantly refer to it) as a highly radicalized individual, the question (however) is whether he really is radicalized (whether his identity is not simply simulated for the reasons like profit, better conditions, etc.).In order to be able to determine (as closely as possible) whether these observed behavioral indicators are manifestations of a highly radicalized andpotentially dangerous individual, it is necessary to correlate them with other methods and data (especially those related to the structure of his or her personality). However, here we are dealing with an absolutely fundamental methodological problem: How to indicate a highly radicalized human being in a standardized and valid way? What are his or her unique personality characteristics? How does he or she think and solve problems? How does he or she experience himself and others? What kind of attitudes and aspirations he or she has? How does this person differ from a group of other "normal" criminals?

The research attempting to define the personality profile of the highly radicalized individual has been done countless times. For example, Vymětal and Śíchová (2017) show (as the main significant personality characteristics of the radicalized individuals in the prison environment) an increased level of aggression, emotional lability and impulsivity. Other observed characteristics (in the connection with these people) were: self-esteem, self-awareness, increased untruthfulness, andlack of adaptability. These people are easy to influence, they are naive and have low self-esteem. The authors state that the most distinctive personality features are: dissociated personality, narcissism, histrionic and schizoid features, anxiety and paranoid orientation of their personality, anddepressive orientation of their personality.

Similarly to Vymětal in the Czech Republic, Baez et al. (2017) also discussed the possibility of indicating specific personal settings of the highly radicalized individual. Researchers compared different psychological aspects influencing and forming these typical features. Their results showed no significant differences in fluid intelligence, verbal intelligence quotient (IQ) or other functions. However, scores on the Motivation for Aggression Inventory (MAI) and the Situation and Aggressive Behavioral Inventory (SABI) revealed a higher frequency of aggressive behavior among terrorists than non-criminals. Terrorists also showed higher levels of proactive aggression than non-criminals which was measured by the Reactive-Proactive Aggression Questionnaire (RPQ).

Research by Baez et al. (2017) points out a methodological problem. How to (based on psychological data) show features which distinguish a criminal from a highly radicalized, potentially dangerous individual? How to (with regard to the psychological aspects) distinguish an extreme radical terrorist from a normal person? Can we understand him as a normal criminal, a non-criminal psychopath or a criminal with a psychopathic personality? Baez et al. based their research on the study by Gao and Tang (2013), who systematically dealt with the question of whether there is any demonstrable correlation between psychopathic and socio-cognitive ways of thinking.In their experiment, they work with a well-known pattern of Greene's experiment $(2001,2003,2004,2007)$. This one observes the neuronal activity of brain during two completely different approaches to the socio-moral dilemma. Greene and his collaborators have been inspired by classical intellectual experiments called "Trolley dilemma" and "Footbridge dilemma," first formulated by Foot (1967) and later by Thomson (1976). The design and interpretation of both dilemmas should demonstrate the principal difference in approach and the way of solving the socio-moral dilemma. According to Foot, Thompson, Greene and others, the dilemma can be accessed in two completely different ways.First, it is necessary to address the socio-moral issue consequently (in a Bentham-Mill way). It means to optimize the good (as much good as possible for as many people as possible). Second, on thebasisofkantiandeontologism-everyonemustfollowgeneral law, regardless of empirical conditions and consequences. According to Greene (2001), the cognitive calculus for the optimization of good is an approach that does not require personal engagement. It actually evolves making decisions about "people-objects" from a distance. As Footor Thomson has pointedout, most people are able to sacrifice one in order to rescue other five if this decision takes place "form a distance". On the contrary, if they have to decide and are also engaged participants in the situation (i.e. to sacrifice one for other five), most of the probands will eventually leave this decision.Greene comes with a completely original and, at the same time, paradoxical (considering the moral philosophy of I. Kant) finding that decision-making on the basis of universal rules or laws requires subjective engagement, including engagement in emotions and empathy. Gao and Tang (like Greene) show that (in the case of a sequential approach) fMRI records neuronal activity only in cognitive-related areas. 
Areas associated with emotions and empathy, such as an Insula, Cingulum, Amygdala, or Orbitofrontal cortex, show minimal activity or no activity at all.

\section{Socio-cognitive Profiling of the Highly Radicalized Subject}

The research of socio-moral emotions has accelerated and has become dominant in today's research of personality psychopathology (Hare, Verplaetse, Gazzaniga, Kreps, Churchland).

Led by Green's paradigm (see above), Gao and Tang (2013) perform research on a relatively large set. They show that people with psychopathic expressions are far more likely to choose the consequential approach to thesolutionof a sociomoraldilemmaratherthanthedeontologicalalone. They confirm a significant correlation between the consequential solution of the socio-moral situation and the psychopathic manifestations of an individual.

When these psychopathically structured individuals had to solve socially cognitive dilemmas, they showed reduced activity in brain areas associated with moral reasoning. Baez et al. (2017) believe that a highly radical individual or even a terrorist thinks likewise. His or her forms of deviant reasoning are not of organic origin. They are influenced by specific socio-cultural environment and ideologies and they are intrinsically identified with them. In the case of psychopaths, we find an organic brain break. In the case of terrorists, there is a deliberate reduction of socio-moral sentiment in order to optimize the means for achieving a higher goal.

Based on these findings, Baez et al. (2017) concludes that a similar correlation can be expected even among criminal psychopaths who had an abnormally high degree of utilitarian judgment during the research and, unlike nonpsychopaths, strongly accepted the fact that an accidental harm to others caused by their actions is likely more acceptable. According to Baez et al., ANOVA test revealed that both radicalized individuals (primarily terrorists) and non-criminal individuals considered behavior or acting with neutral intentions and neutral outcomes more tolerable than behavior or acting with negative intentions $(\mathrm{F}(1,130)=621.56, \mathrm{p}<0.01, \mathrm{n} 2=0.82)$. However, in contrast to the non-criminal group, extremely radicalized individuals (terrorists) considered accidental injury as less acceptable ( $p$ $<0.01)$ and deliberate harm as more acceptable $(\mathrm{p}<0.01)$.

\section{Conclusion}

In summary, based on outputs from current empirical research (eg Baez 2017), it can be concluded that the personal socio-cognitive profile of the highly radicalized individual can not be interpreted on the basis of psychopathy. The fact is supported by the evidence that not all psychopaths behave criminally. ${ }^{4}$ Similarly, we do not record any clearly reportable line leading to radicalization ${ }^{5}$ On the other hand, the deformation of socio-moral reasoning is a characteristic which distinguishes the highly radicalized individual from criminal psychopaths.Baez at al.(2017), on the basis of their findings, believe that the socio-moral cognition (respectively its specific consequential form) is obviously the very essential personality premise distinguishing highly radicalized individuals from all others. Persons with this attitude judge the situation completely purposefully. The victims are only the necessary means for achieving a higher goal. The degree of tolerance (towards the harm caused to the others) is much greater than in the other monitored groups. "Results reveal that terrorists judge others' actions by focusing on the outcomes, suggesting that their moral code prioritizes ends over means. Although the well documented taxonomy of behavioral manifestations (attributed to the radicalized individual) enables us to have a high quality identification, the needs of today's society are more demanding. Society - security forces - the prison facilities are confronted with the need to recognize these individuals before they show their attitude, before they become radicalized at such a level which represents a social risk.

In order to make our knowledge work in a preventive way, we have to have valid instruments and methods that enable us to objectively recognize and identify their specific personality profile. It is necessary to have a method that allows us to recognize whether an investigated subject is a potential radical, an extremist or a terrorist, or simply "behaves" and simulates the identity of a radicalized individual. We believe that comprehensive research (leading to the preventive identification of these socially dangerous individuals) cannot be accomplished without an advanced multidisciplinary method that reflects the relationships between key behavioral and personality indicators. Without establishing and clarifying these mutual methodological relationships, it is not possible to say who a truly, highly radical individual or terrorist is. And if we do not know who he or she is and how to recognize him or her objectivelyin time, such an individual is a risk to society (who, when, where) that is almost unpredictable.

\footnotetext{
${ }^{4}$ SeeVictoro , J. (2005). The mind of the terrorist. A review and critique of psychological approaches. J. Conflict Resolut. 49, $3-42$.

5See Crenshaw, M. (19992) Terrorism: Roots, Impact, Responses (ed. Howard, L.) 71-80.
} 


\section{Books and References}

ASHOUR, O., BOUCEK, C. De-Radicalization in Egypt, Algeria, and Libya [online]. 2009 [cit. May 2, 2014]. Washington, DC, Carnegie Endowment for Inter-national Peace, April 16. Available at: WWW: http://carnegieendowment.org/2009/04/16/de-radicalization-in-egypt-algeria-and-libya/201v.

BAEZ, S., HERRERA, E., GARCÍA, A. M., MANES, F., YOUNG, L., IBÁÑEZ, A. (2017). Outcome-oriented moral evaluation in terrorists. NATURE HUMAN BEHAVIOUR 1, 0118.

COPPRA - Manual for trainers, Published by: Federal Police, Belgium, 2009.

DALGAARD-NIELSEN, A. (2008). Studying violent radicalization in Europe II. The potential contribution of sociopsychological and psychological approaches, DIIS Working Paper no 2008/3, Copenhagen. ISBN: 978-877605-250-8

DANICS, Š; TEJCHMANOVÁ, L. (2017). Extremismus, radikalismus, populismus a euroskepticismus. 1. ed. Praha: UJAK, 2017, p. 80. ISBN 978-80-7452-122-5.

DELLA, P. D. \& LAFREE, G. (2012). Processes of radicalization and de-radicalization. International Journal of Conflict and Violence, 6 (1), pp. 4-10.

FAIOLA, A., KOTTOOR, N. and PITRELLI, P. (2017). Suspect in Berlin market attack was radicalized in an Italian jail. [online]. Available at: https://www.washingtonpost.com/world/europe-searches-for-suspect-berlinchristmas-market-attack/2016/12/22/78502d7e-c7e0-11e6-acda59924caa2450_story.html?utm_term=.56204354c9cd

FOOT, Ph. (1967). The Problem of Abortion and the Doctrine of the Double Effect in Virtues and Vices (Oxford: Basil Blackwell, 1978) (originally appeared in the Oxford Review, Number 5.

FOREST, JAMES J. F. (2012). The Terrorism Lectures, Orange Country: Nortia Press.

GAO ,Y.,TANG, S. (2013). Psychopathic personality and utilitarian. moraljudgment in collegestudents. JournalofCriminal Justice 41 (2013) 342-349.

GAZZANIGA, M., S. (2008). Human. HarperCollins Publishers, e-book.

GREENE, J. D. (2003). From neural "is" to moral "ought": What are the moral implications of neuroscientific moral psychology? Nature Reviews Neuroscience, 4, 847-850.

GREENE, J. D. (2007). Why are VMPFC patients more utilitarian? A dual-process theory of moral judgment explains. Trends in Cognitive Sciences, 11(8), 322-323.

GREENE, J. D., Nystrom, L. E., Engell, A. D., Darley, J. M., \& Cohen, J. D. (2004). The neural bases of cognitive conflict and control in moral judgment. Neuron, 44(2), 389-400.

GREENE, J. D., Sommerville, R. B., Nystrom, L. E., Darley, J. M., \& Cohen, J. D. (2001). An fMRI investigation of emotional engagement in moral judgment. Science, 293, 2105-2108.

HARE, R. D. (1993). Without conscience: The disturbing world of the psychopaths among us. New York: Pocket Books.

HARE, R. D. (1996). Psychopathy and antisocial personality disorder: A case of diagnostic confusion. Psychiatric Times, 13(2), 39-40.

HARE, R. D. (1998). Psychopaths and their nature: Implications for the mental health and criminal justice systems. In E. Theodore Millon, E. Erik Simonsen, M. Birket- Smith, \& R. D. Davis (Eds.), Psychopathy: Antisocial, criminal, and violent behavior (pp. 188-212). New York: Guilford.

HARE, R. D. (2003). Manual for the Hare Psychopathy Checklist—revised (2nd ed.). Toronto: Multi-Health Systems.

HOLLY F. YOUNG, FrederikeZwenk, Magda Rooze: A review of the literature on radicalization; and what it means for TERRA, May 2013.

HORGAN, J., BRADDOCK, K. Rehabilitating the terrorists? Challenges in asses-sing the effectiveness of deradicalization programs [online]. 2010 [cit. May 2, 2014]. In Terrorism and Political Violence, 22 (2), pp. 26729. Available at: WWW: http://www.start.umd.edu/sites/default/files/files/publications/Derad.pdf.

CHURCHLAND, P. (1989). Brain-Wise. Cambridge: MIT.

CHURCHLAND, P. (2011). Braintrust: What Neuroscience Tells Us about Morality. New Jersey: Princeton University Press.

ILARDI. Joe, Gaetano. Prison Radicalization - The Devil is in the Detail. Victoria Police Adjunct Research Associate, Global Terrorism Research Centre Monash University. [online]. [cit. June 11, 2017]. Available at: http://artsonline.monash.edu.au/radicalisation/files/2013/03/conference-2010-prison-radicalisation-gji.pdf

KRÁMSKÝ, D., PREISS, M. (2014). Filosofická a psychologickávýchodiskastudiamorálníhousuzování. Československápsychologie, 58, 2, pp. 107-119.

KREBS, D. (2011). The Origins of Morality. An Evolutionary Account. New York: Oxford University Press. 
MOLL, J., \& de OLIVEIRA-SOUZA, R. (2007a). Moral judgments, emotions and the utilitarian brain. Trends Cogn. Sci.

MOLL, J., \& de OLIVEIRA-SOUZA, R. (2007b). Response to Greene: Moral sentiments and rea- son: Friends or foes? Trends Cogn. Sci., 11(8), 323-324.

MOLL, J., de OLIVEIRA-SOUZA, R., \& ESLINGER, P. J. (2003). Morals and the human brain: A work- ing model. Neuroreport, 14(3), 299-305.

MOLL, J., de OLIVEIRA-SOUZA, R., BRAMATI, I. E., \& GRAFMAN, J. (2002a). Functional networks in emotional moral and nonmoral social judgments. Neuroimage, 16(3 Pt 1), 696-703.

PILNER, J. (2013). Observable Indicators Of Possible Radicalisation. An Overview of the SAFIRE Project: A Scientific Approach to Finding Indicators and Responses to RadicalizationISCA.

PRECHT, T. (2007). Home grown terrorism and Islamist radicalization in Europe . From conversion to terrorism. An assessment of the factors influencing violent Islamist extremism and suggestions for counter radicalization measures Det. Research report funded by the Danish Ministry of Justice.

Safe Campus Communities: Radicalization Literature Review [online]. 2016 [cit. October 2, 2017]. Available at: WWW: http://www.safecampuscommunities.ac.uk/uploads/editor/files/Radicalisation_Research_Summary_912-16.pdf

SCHMID, A. P. (2013). Radicalization, DeRadicalization, Counter-Radicalization: A Conceptual Discussion and Literature Review [online]. 2013 [cit. May 2, 2014]. ICCT Research Paper. The International Centre for Counter-Terrorism (ICCT) -The Hague. Available at: WWW: http://www.icct.nl/download/file/ICCT-SchmidRadicalisation-De-Radicalisation-Counter-Radicalisation-March-2013.pdf.

STÖSS, R. (1999). Rechtsextremismusimvereinten Deutschland. Bonn: Friedrich Ebert Stiftung, pp. 18-19.

THOMSON, J. J. (1976). Killing, Letting Die, and the Trolley Problem. The Monist., no. 59, pp. 204-217

VERPLAETSE, J. et al. (2009). The Moral Brain. New York: Springer.

VETEŠKA, J. (2016). Přehledandragogiky. Praha: Portál. 